\title{
Mating system parameters in a natural population of Abies borisii regis Mattfeld
}

\author{
B Fady ${ }^{*}$, RD Westfall ${ }^{2}$ \\ 'Unité expérimentale d'amélioration des arbres forestiers méditerranéens, Inra, \\ domaine du Ruscas, 4935, route du Dom, 83230 Bormes-Les-Mimosas, France \\ ${ }^{2}$ Pacific Southwest Research Station, Institute of Forest Genetics, USDA Forest Service, \\ PO Box 245, Berkeley, CA 9470I, USA
}

(Received 29 July 1996; accepted 12 May 1997)

\begin{abstract}
Summary - Isozymes were used to estimate mating system parameters of one natural Abies borisii regis population from the Pertouli forest, Thessaly, Greece. Starch gel electrophoresis was performed and 17 trees were genotyped for seven variable loci using open-pollinated seeds. Under the mixed mating model, selfing rate was significantly different from zero although outcrossing accounted for $94 \%$ of all zygotes formed. The parental fixation index was significantly lower than zero, indicating heterozygote excess. A limited number of parents was shown to participate in the matings.
\end{abstract}

\section{Abies borisii regis / allozyme / outcrossing / inbreeding / hybridization}

Résumé - Régime de reproduction d'une population naturelle d'Abies borisii regis Mattfeld. Les isoenzymes ont été utilisés pour estimer les paramètres du régime de reproduction d'une population naturelle d'Abies borisii regis issue de la forêt de Pertouli, région de Thessalie, en Grèce. Les descendances issues de fécondation libre d'un sous-échantillon de 17 arbres parmi les 30 récoltés ont été analysées par électrophorèse horizontale sur gel d'amidon selon la méthode classique du "mixed mating model". Sur un total de 14 loci (neuf systèmes enzymatiques révélés), sept loci polymorphes ont été utilisés dans cette étude. Le taux d'autofécondation est apparu significativement différent de zéro bien que $94 \%$ des zygotes formés étaient issus d'allofécondation. L'index de fixation parental était significativement négatif, indiquant un excès d'hétérozygotes dans la population. Un nombre limité de parents participent effectivement à la reproduction.

Abies borisii regis / allozyme / allofécondation / consanguinité / hybridation

* Correspondence and reprints

Tel: (33) 04940532 10; fax: (33) 04940532 11; e-mail: Fady@avignon.inra.fr 


\section{INTRODUCTION}

Abies borisii regis is a fir species endemic to the mountains of central and northern Greece. Little information is available on the mating system of Abies species in general and of this species in particular. As this species and the supposed-to-be related Abies cephalonica are used in breeding programs in southern France, it is important to have accurate estimates of mating system parameters for the study of adaptative trait genetic parameters and for developing selection methods in wild stands (Ledig, 1974). In this study, isozymes were used to estimate mating system parameters in one $A$ borisii regis population and to try to explain the excess of heterozygotes found in the data from Fady and Conkle (1993) although related species such as $A$ cephalonica and $A$ alba were heterozygote deficient.

\section{MATERIAL AND METHODS}

Wind-pollinated seeds were collected on 30) trees from one provenance of $A$ borisii regis (Pertouli, Pindos mountains, Greece, $39^{\circ} 30 \mathrm{~N} ; 21^{\circ} 30 \mathrm{E}$; northern part of the range). Trees were separated by at least $30 \mathrm{~m}$. Germination was high enough in only 17 families to accurately determine mother-tree genotype. Electrophoretic and stain procedures are described in Fady and Conkle (1992).

A total of 14 loci from nine enzyme systems were scored. All electrophoretic variants followed Mendelian expectations, except ACO and 6-PGD where distortion was shown on the few heterozygote mother trees tested (Fady and Conkle, 1992). However, both loci demonstrated Mendelian inheritance in another Abies species (Neale and Adams, 1981). Of the 14 loci, two were fixed in the maternal parent and nearly fixed in the pollen pool. In addition, a preliminary analysis indicated that five loci were poorly behaved and were omitted for the mating system analysis. With the exception of a LAP locus, the omitted loci were those where the frequency of the common allele was greater than 0.90 . The following seven loci were thus used to estimate allele frequencies: Aco, Got 2, Got 3, Gr, Mnrl, Pgil and
Pgi2. Sample size per locus varied between 257 and 353.

Mating system parameters were estimated under the mixed mating model using Ritland's generalized multilocus estimation programs, MLTF (multilocus t and F, Ritland 1990a) and MLTR, an extension of MLT (Ritland, 1990b) that also estimates parental correlations. The former program, MLTF, is based on the 'conifer' model, whereby maternal and paternal alleles can be identified from megagametophytic and embryo tissues in seeds from gymnosperms: the most likely maternal genotype is assigned from megagametophytic genotypes when one or both alleles of the maternal genotype are omitted from the data. In MLTF, mating system parameters are estimated by maximum likelihood and standard errors estimated from the inversion of the information matrix (Ritland 1986). In MLTR, standard errors are computed by bootstrap resampling of families, re-estimating parameters by maximum likelihood using initial parameter estimates and the most likely maternal genotypes as seeds in each bootstrap iteration. We conducted two analyses. In the first, pollen and ovule allelic frequencies, the parental fixation index $\left(F_{\mathrm{p}}\right)$, single and multilocus outcrossing rates $\left(t_{\mathrm{s}}\right.$ and $t_{\mathrm{m}}$, respectively), the correlation of outcrossing rates $\left(r_{t}\right)$ and the correlation of pollen genotypes $\left(r_{\mathrm{p}}\right)$ (Ritland, 1989) were estimated from the 17 families noted above, whereby the maternal genotype, estimated from megagametophytic segregations, was included with zygote genotypes in each family. All parameters were estimated by the Newton-Raphson algorithm except pollen frequencies and $r_{p}$, which were estimated by the expectation-maximization method. Standard errors and 95\% confidence intervals were computed in MLTR by a 500-sample bootstrap. Through single family analysis, we estimated the correlation between maternal genotypes and outcross pollen frequencies $\left(r_{c}\right)$, and thus the extent of consanguineous matings. In the second analysis, the zygote fixation index $\left(F_{z}\right)$ was estimated from a bulked sample that also included progenies from excluded families.

\section{RESULTS}

Pollen and ovule allele frequencies were not significantly different. Chi square tests computed for each locus showed no significant distortion between observed and expected 
Table I. Mating system estimates in a population of Abies borisii regis using two methods (see text). Standard deviations in parentheses. $\mathrm{CI}=$ confidence interval.

\begin{tabular}{lccc}
\hline & MLTF & \multicolumn{2}{c}{ MLTR } \\
\cline { 3 - 4 } Statistic & Estimate & Estimate & $95 \% C I$ \\
\hline$F_{\mathrm{z}}$ & $0.065(0.021)$ & - & - \\
$F_{\mathrm{p}}$ & $-0.245(0.105)$ & $-0.267(0.134)$ & $-0.601 /-0.099$ \\
$t_{\mathrm{s}}$ & 0.965 & $0.950(0.038)$ & $0.873 / 1.023$ \\
$t_{\mathrm{m}}$ & $0.940(0.016)$ & $0.952(0.022)$ & $0.906 / 0.995$ \\
$r_{\mathrm{t}}$ & - & $0.258(0.369)$ & $-0.510 / 0.990$ \\
$r_{\mathrm{p}}$ & - & $0.990(0.011)$ & $0.990 / 0.990$ \\
\hline
\end{tabular}

offspring genotypes using inferred maternal parameters.

Single-locus $\left(t_{\mathrm{s}}\right)$ and multilocus $\left(t_{\mathrm{m}}\right)$ outcrossing rate estimates are listed in table I. Although little selfing was estimated, $t_{\mathrm{m}}$ is significantly different from 1.00 at the $5 \%$ level, although $t_{\mathrm{s}}$ is not. If only random mating were to be expected, the level of inbreeding should be $F_{\mathrm{e}}=0.024 \quad\left[F_{\mathrm{e}}=\right.$ $\left.\left(1-t_{\mathrm{m}}\right) /\left(1+t_{\mathrm{m}}\right)\right]$. This value was similar to that of the bulked sample $\left(F_{\mathrm{z}}=0.065 \pm\right.$ 0.021 ). In contrast, the estimate of maternal fixation index was $F_{\mathrm{m}}=-0.245 \pm 0.105$ (by MLTF; by MLTR, $F_{\mathrm{m}}=-0.267 \pm$ 0.134 ), indicating, instead, a significant excess of heterozygotes.

\section{DISCUSSION}

A borisii regis is predominantly outcrossed $\left(t_{\mathrm{m}}=0.94\right)$. Although this value must be considered cautiously as sampled trees were separated by approximately $30 \mathrm{~m}$, which is a limitation for intercrossing, similar values were recorded for other Abies: $A$ alba, $t_{\mathrm{m}}=0.89$ (Schroeder, 1989); A lasiocarpa, $t_{\mathrm{m}}=0.89$ (Shea, 1987); A balsamea, $t_{\mathrm{m}}=$ 0.89 (Neale and Adams, 1985). This is in good concordance with phenological and biological observations made for the species or related Abies: monoecious plants, wind pollination, female flowers erect on lateral shoots in the upper part of the crown, male flowers on the underside of lateral shoots in the lower part of the crown. However, selfing occurs $6 \%$ of the time, indicating that self-incompatibility is not present in this fir. Values for mean $t_{\mathrm{s}}$ and $t_{\mathrm{m}}$ are not significantly different, which indicates that there is no reduction as a result of consanguineous matings. This is supported by a low correlation between maternal genotypes and outcross pollen frequencies $\left(r_{\mathrm{c}}=\right.$ 0.0346). The actual rate of selfing in this population may be higher, however. Mixed mating is frequent among conifers: eg, Pseudotsuga mensiezii (6.4\% selfing) and Pinus ponderosa (11.3\% selfing) according to Sorensen and Miles (1974); A balsamea ( $11 \%$ selfing) according to Neale and Adams (1985). Sorensen (1982) indicated that most embryos resulting from self-pollination in conifers are aborted. Since the percentage of empty seeds was quite high in this population of $A$ borisii regis $(60 \%$ on average), actual self-pollination could be much higher than the $6 \%$ found in this study.

Heterozygote excess in A borisii regis is significantly high $\left(F_{\text {is }}=-0.245\right)$. For the same population, the estimate for $F_{\text {is }}$ was higher $(-0.122)$ in Fady and Conkle (1993), but there were more parent trees (19) and more loci in the sample. The additional loci, excluded in our study, were mainly near fix- 
ation and with lower values of $F_{\text {is }}$ (Fady and Conkle, 1993, table 3). Moreover, the estimate for $\mathrm{F}_{\text {is }}$ in Fady and Conkle (1993) is well within the $95 \%$ confidence interval for the estimate in this study. In contrast, heterozygote deficiencies were found in bulked seed samples of the closely related fir species $A$ alba and $A$ cephalonica $(F$ is $=$ 0.234 and 0.181 , respectively) by Fady and Conkle (1993). Although the structure of the sample alone could be responsible for this difference (bulked seeds versus maternal genotypes), it is interesting to note that $A$ borisii regis is thought to be a post-glacial hybrid between $A$ alba and $A$ cephalonica and that high heterozygote excess could possibly result from the combination of gene pools from different origins. However, our data are not well suited to test for this hypothesis. An alternative hypothesis is that individuals from self-pollinations and consanguineous matings are purged from a cohort as the cohort matures. Reductions in $F$ between seedling and mature cohorts are common in conifers and Ledig (1986) has speculated that such purges of inbreds are responsible for this.

Though $F_{\mathrm{p}}$ was significantly lower than zero, its confidence interval was quite large, indicating substantial family to family variation of the estimate. Thus, much larger numbers of families would be needed for a more precise estimate of $F_{\mathrm{p}}$.

A curious result in our data was the very large correlation among progeny pairs for parental genotypes $\left(r_{\mathrm{p}}=0.990\right)$, which was nearly invariant among families ( $\mathrm{SD}=$ $0.014)$. The proportion of full-sib progeny pairs, from $\left[t^{2}\left(1-r_{\mathrm{s}}\right)+t r_{\mathrm{s}}\right] r_{\mathrm{p}}$ (Ritland, 1989), is 0.91 , indicating that a very limited number of males participated in the matings per female within this sample of the stand. Although aggregated over the families, these were representative of the stand, because pollen allelic frequencies were similar to those of the ovules. However, outcross pollen frequencies in each family lend sup- port to the statistical data: a substantial proportion of these frequencies are nearly fixed or near 0.5 . In addition, outcross pollen frequencies in some families were highly correlated with those in others. Furthermore, the genotypes of a few maternal parents were correlated $(>0.70)$ with pollen frequencies in some families.

To examine in detail the possibility that a limited number of parents participated in the matings, we used Neale's (1983) maximum-likelihood method to determine the most probable pollen parents in each family, given the set of 17 maternal parents. To maximize the precision of the assignments, we used all available polymorphic loci in the analysis, which was based on the most likely maternal genotypes and the haploid pollen genotype of each zygote. In 59\% (10 out of 17) of the families, we found two females, identical in genotype, that were among the most likely male parents in more than $25 \%$ of the matings. If two more parents differing in genotype are included, these three genotypes are among the most likely parents in $40 \%$ of the matings in $59 \%$ (10 out of 17) of the families. Moreover, there was a tendency for the three genotypes to be equal to the largest or next largest in likelihood in matings where the likelihoods of these genotypes were greater than zero. In an additional family, two entirely different parents than the three mentioned above, contributed to $50 \%$ of the matings. Even with this apparent commonality of parentage, $18 \%$ of the total matings were from individuals outside the collection of 17 parents.

This mating pattern, where progenies are more closely related than half-sibs, if repeated over time, would suggest a stand structure of sib-clusters, which in turn would increase the frequency of consanguineous matings and, consequently, the parental fixation index. However, the maternal $F$ is significantly negative and the proportion of consanguineous matings is low. Potential explanations for this dilemma are first that 
family clusters do not extend much beyond $30 \mathrm{~m}$, the minimum distance between the parents selected in this study. This view is supported by the relatively heavy seed weight, which makes the seeds tend to fall close to the seed-bearing tree. Second, there is reduced seed viability in the cohort resulting from consanguineous matings. This hypothesis is supported by the low percentage of viable seeds in our seedlots. Finally, the limited number of parents could be transitory. Few parents contribute to most of the matings during poor seed years, but the dominant parents tend to change from year to year (El-Kassaby et al, 1989; Fowells and Shubert, 1956). In addition, the periodic mast years are typified by relatively equal contributions of parentage (Fowells and Shubert, 1956). Our results have important implications in the selection of plus trees and in the conservation of wild populations of $A$ borisii regis. The lack of consanguineous matings suggests that nearest neighbors are unrelated. Thus, the comparison tree method can be an effective method for selecting plus trees (Ledig, 1974). However the full-sib structure of the families and evidence for severe reductions in seed viability, if widespread in the species, would increase the risk of accidental population losses through demographic accidents (Lande, 1988).

Acknowledgements: This work was performed at the Institute of Forest Genetics, Placerville, California. The authors are grateful to $P$ Hodgskiss for technical assistance. This study was made possible by a grant from the French Ministry of Foreign Affairs (Bourse Lavoisier). Special thanks to Professor Panetsos for cone collection in the University of Thessaloniki Pertouli Forest in Greece, Dr F Lefèvre, Dr C Pichot and two anonymous reviewers for helpful comments on the manuscript.

\section{REFERENCES}

El-Kassaby YA, Fashler AM, Crown M (1989) Variation in fruitfulness in a Douglas-fir seed orchard and its effect on crop-management decisions. Silvate Genet 38 (3-4), I13-121

Fady B, Conkle MT (1992) Segregation and linkage of allozymes in seed tissues of the hybrid Greek fir Abies borisii regis Mattfeld. Silvae Genet 41 (4-5), 273-278

Fady B, Conkle MT (1993) Allozyme variation and possible phylogenetic implications in Abies cephalonica Loudon and some related eastern Mediterranean firs. Silvae Genet 42 (6), 351-359

Fowells HA, Shubert GH (1956) Seed crops of forest trees in the pine region of California. USDA Techn Bull $\mathrm{n}^{\circ} 1150$

Lande, R. 1988. Genetics and demography in biological conservation. Science 241, 1455-1460

Ledig FT (1974) An analysis of methods for the selection of trees from wild stands. Forest Sci 20 (1), 2-16

Neale DB (1983) Population genetic structure of the Douglas-fir shelterwood regeneration system in southwest Oregon. PhD dissertation, Oregon State University

Neale DB, Adams WT (1981) Inheritance of isozyme variants in seed tissues of balsam fir (Abies balsamea). Can J Bot 59, 1285-1291

Neale DB, Adams WT (1985) Allozyme and matingsystem variation in balsam fir (Abies balsamea) across a continuous elevational transect. Can J Bot $63,2448-2453$

Ritland K (1986) Joint maximum likelihood estimation of genetic and mating structure using openpollinated progenies. Biometrics 42 (3), 25-43

Ritland K (1989) Correlated matings in the partial selfer Mimulus guttatus. Evolution 43 (4), 848-859

Ritland K (1990a) Generalized multilocus estimation program. MLTF. Revised version, Toronto

Ritland K (1990b) A series of Fortran computer programs for estimating plant mating systems. J Hered 81, 235-237

Shea KL (1987) Effects of population structure and cone production on outcrossing rates in Engelmann spruce and subalpine fir. Evolution $41(1), 124-136$

Schroeder S (1989) Outcrossing rates and seed characteristics in damaged natural populations of Abies alba Mill. Silvae Genet 38 (5-6), 185189

Sorensen FC (1982) The roles of polyembryony and embryo viability in the genetic system of conifers. Evolution (Lawrence, Kansas) 36, 725-733

Sorensen FC. Miles RS (1974) Self-pollination effects on Douglas fir and ponderosa pine seedlings. Silvae Genet 23, 135-138 